\title{
Mesoporous Metal-Containing Carbon Nitrides for Improved Photocatalytic Activities
}

\author{
Jie Luo, ${ }^{1}$ Zhao-Jie Cui, ${ }^{1}$ and Guo-Long Zang ${ }^{2}$ \\ ${ }^{1}$ School of Environmental Science and Engineering, Shandong University, Jinan 250100, China \\ ${ }^{2}$ Tianjin Renewable Resources Institute, All China Federation of Supply and Marketing Cooperatives, Tianjin 300191, China \\ Correspondence should be addressed to Zhao-Jie Cui; cuizj@sdu.edu.cn and Guo-Long Zang; guolongz@gmail.com
}

Received 30 September 2013; Accepted 14 October 2013

Academic Editor: Tifeng Jiao

Copyright (c) 2013 Jie Luo et al. This is an open access article distributed under the Creative Commons Attribution License, which permits unrestricted use, distribution, and reproduction in any medium, provided the original work is properly cited.

\begin{abstract}
Graphitic carbon nitrides $\left(\mathrm{g}-\mathrm{C}_{3} \mathrm{~N}_{4}\right)$ have attracted increasing interest due to their unusual properties and promising applications in water splitting, heterogeneous catalysis, and organic contaminant degradation. In this study, a new method was developed for the synthesis of mesoporous Fe contained g- $\mathrm{C}_{3} \mathrm{~N}_{4}\left(\mathrm{~m}-\mathrm{Fe}-\mathrm{C}_{3} \mathrm{~N}_{4}\right)$ photocatalyst by using $\mathrm{SiO}_{2}$ nanoparticles as hard template and dicyandiamide as precursor. The physicochemical properties of $\mathrm{m}-\mathrm{Fe}-\mathrm{C}_{3} \mathrm{~N}_{4}$ were thoroughly investigated. The XRD and XPS results indicated that $\mathrm{Fe}$ was strongly coordinated with the $\mathrm{g}-\mathrm{C}_{3} \mathrm{~N}_{4}$ matrix and that the doping and mesoporous structure partially deteriorated its crystalline structure. The UV-visible absorption spectra revealed that $\mathrm{m}-\mathrm{Fe}-\mathrm{C}_{3} \mathrm{~N}_{4}$ with a unique electronic structure displays an increased band gap in combination with a slightly reduced absorbance, implying that mesoporous structure modified the electronic properties of $\mathrm{g}-\mathrm{Fe}-\mathrm{C}_{3} \mathrm{~N}_{4}$. The photocatalytic activity of $\mathrm{m}-\mathrm{Fe}-\mathrm{C}_{3} \mathrm{~N}_{4}$ for photodegradation of Rhodamine $\mathrm{B}$ (RhB) was much higher than that of $\mathrm{g}-\mathrm{Fe}-\mathrm{C}_{3} \mathrm{~N}_{4}$, clearly demonstrating porous structure positive effect.
\end{abstract}

\section{Introduction}

Carbon nitride has been widely regarded as the most promising candidate to complement carbon in materials applications. Among various carbon nitride compounds, graphitic carbon nitride $\left(\mathrm{g}-\mathrm{C}_{3} \mathrm{~N}_{4}\right)$ is the most stable allotrope, which has attracted much attention for its potential application in splitting water, decomposing organic pollutants, and photosynthesis under visible light [1-5]. The polymeric $g-\mathrm{C}_{3} \mathrm{~N}_{4}$ material contains graphitic stacking of $\mathrm{C}_{3} \mathrm{~N}_{4}$ layers, which are constructed from tri-s-triazine units connected by planar amino groups $[2,6]$. To further improve the performance of g- $\mathrm{C}_{3} \mathrm{~N}_{4}$, many methods such as introducing functional atoms (B, F, S, P, etc.), controlling shape, and oxidation reaction have been used for its modification [1,7-10].

One important way to improve its light utilization efficiency is to reduce the band gap and extend the light absorption range. Metal element dopants are usually introduced to prepare functional organic-metal hybrid material based on $\mathrm{g}_{-} \mathrm{C}_{3} \mathrm{~N}_{4}$. Wang et al. firstly reported the synthesis of metal $\left(\mathrm{Fe}^{3+}\right)$-containing carbon nitride compounds using dicyandiamide and metal chloride as precursors, and such synthesized carbon nitride showed high photocatalytic activities for the degradation of various organic dyes [11]. g- $\mathrm{C}_{3} \mathrm{~N}_{4}$ photocatalyst was also modified with other transition metal elements (Co, $\mathrm{Ni}, \mathrm{Mn}, \mathrm{Cu}$ [12], or $\mathrm{Zn}$ [13]) to obtain the high photocatalytic activity and good stability. It also was active for the direct oxidation of benzene to phenol using hydrogen peroxide [14].

The porous structure can increase the semiconductor surface area, which contributes to an enhancement in energy conversion efficiency $[15,16]$. Herein, we report the synthesis of porous $\mathrm{m}-\mathrm{Fe}-\mathrm{C}_{3} \mathrm{~N}_{4}$ photocatalysts by using $\mathrm{SiO}_{2}$ nanoparticles as template and dicyandiamide as precursor, and the physicochemical properties of synthesized $\mathrm{m}-\mathrm{Fe}-\mathrm{C}_{3} \mathrm{~N}_{4}$ and g$\mathrm{Fe}-\mathrm{C}_{3} \mathrm{~N}_{4}$ were characterized by X-ray diffractometer (XRD), transmission electron microscopy (TEM), UV-visible spectrophotometer (UV-vis), X-ray photoelectron spectroscopy (XPS), Fourier transform infrared (FTIR) spectra, and $\mathrm{N}_{2}$ adsorption-desorption measurement. Moreover, their performance for photodegradation of Rhodamine $\mathrm{B}(\mathrm{RhB})$ was evaluated. 


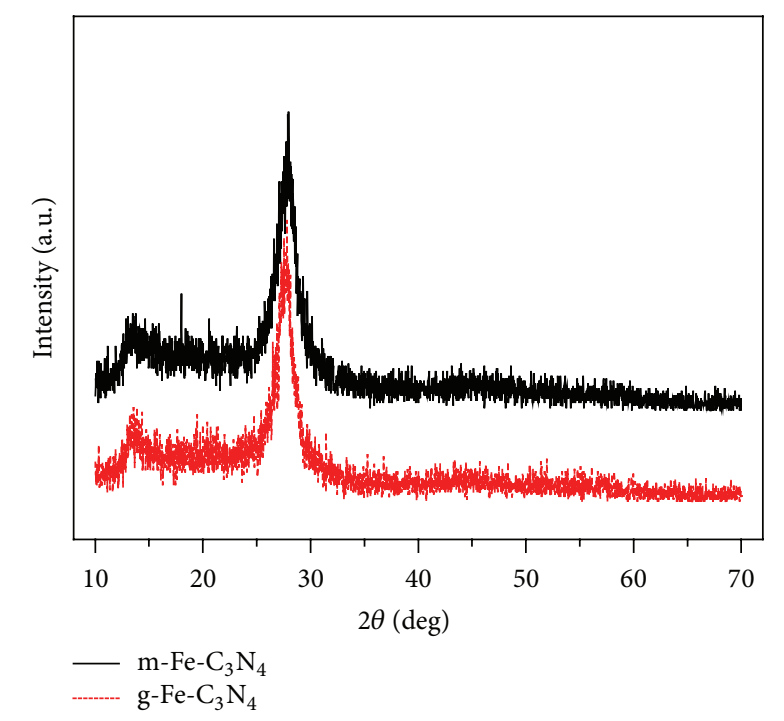

Figure 1: XRD patterns of the g-Fe- $\mathrm{C}_{3} \mathrm{~N}_{4}$ and m-Fe- $\mathrm{C}_{3} \mathrm{~N}_{4}$ samples.

\section{Materials and Methods}

2.1. Preparation of $g-F e-C_{3} N_{4}$. Graphitic metal-containing carbon nitride compounds were synthesized according to the procedure reported previously [11]. Dicyandiamide was mixed with $0.12 \mathrm{~g} \mathrm{FeCl}_{3}$ in water $(20 \mathrm{~mL})$ under stirring, and then the mixed solution was heated at $100^{\circ} \mathrm{C}$ to remove water. The resulting powder was then heated at a rate of $2.3^{\circ} \mathrm{C} \mathrm{min}{ }^{-1}$ for about $4 \mathrm{~h}$ to reach a temperature of $550^{\circ} \mathrm{C}$ and then held at this temperature for an additional $4 \mathrm{~h}$ under flowing nitrogen gas. The sample was then cooled to room temperature and was denoted as g-Fe- $\mathrm{C}_{3} \mathrm{~N}_{4}$.

2.2. Preparation of $m-\mathrm{Fe}-\mathrm{C}_{3} N_{4}$. A $5 \mathrm{wt} \%$ dispersion of $15 \pm$ $5 \mathrm{~nm} \mathrm{SiO}{ }_{2}$ particles in water $(20 \mathrm{~mL})$ was heated and stirred at $100^{\circ} \mathrm{C}$ with dicyandiamide ( $4 \mathrm{~g}$, Aldrich) and $\mathrm{FeCl}_{3}(0.12 \mathrm{~g})$ added. The mixed solution was treated following the same procedures as mentioned above to obtain high-temperature power. The resulting power was then stirred in $200 \mathrm{~mL}$ of $4 \mathrm{~mol} / \mathrm{L} \mathrm{NH}_{4} \mathrm{HF}_{2}$ for $12 \mathrm{~h}$, followed by filtration and washing with water. After that, the sample was cooled to room temperature and was denoted as $\mathrm{m}-\mathrm{Fe}-\mathrm{C}_{3} \mathrm{~N}_{4}$.

\section{Characterization}

The morphology of the samples were observed using transmission electron microscopy (TEM, JEM-2011, JEOL Co., Japan). The nitrogen adsorption-desorption isotherms and Brunauer-Emmett-Teller (BET) surface areas were measured using a TriStar II $3020 \mathrm{M}$ instrument at $77 \mathrm{~K}$. The crystal properties of the samples were identified by an $18 \mathrm{~kW}$ rotating anode X-ray diffractometer (MAP18AHF, MAC Sci. Co., Japan). The optical absorbance spectra of the samples were recorded using a UV-visible spectrophotometer (SolidSpec3700, Shimadzu Co., Japan). The samples were ground with $\mathrm{KBr}$ power and pressed to form a uniform disk prior to FTIR analysis (Magna-IR 750, Nicolet Instrument Co., USA).

\section{Photocatalytic Activity Measurement}

Photocatalytic activities of samples for RhB degradation were evaluated with irradiation by a $500 \mathrm{~W}$ Xe lamp. In a Pyrex glass reactor, a total amount of $20 \mathrm{mg}$ photocatalyst powder was dispersed in $40 \mathrm{~mL}$ of $5 \mathrm{mg} \mathrm{L}^{-1}$ aqueous solution of $\mathrm{RhB}$. One $\mathrm{mL}$ suspension was sampled at fixed time intervals during the reaction. The suspension was centrifuged to remove the photocatalyst and then the concentration variation of $\mathrm{RhB}$ was examined by $\mathrm{UV}$-vis spectrophotometer (UV-2450, Shimadzu Co., Japan).

\section{Results and Discussion}

XRD data obtained from both $\mathrm{g}-\mathrm{Fe}-\mathrm{C}_{3} \mathrm{~N}_{4}$ and $\mathrm{m}-\mathrm{Fe}-\mathrm{C}_{3} \mathrm{~N}_{4}$ are illustrated in Figure 1. All these patterns indicate a structural similarity between g-Fe- $\mathrm{C}_{3} \mathrm{~N}_{4}$ and $\mathrm{m}-\mathrm{Fe}-\mathrm{C}_{3} \mathrm{~N}_{4}$. There were two peaks in both samples. The strongest peak at 27.6, corresponding to an interlayer distance of $0.33 \mathrm{~nm}$, could be indexed as the (002) peak of the stacking of the conjugated aromatic system [17]. However, XRD peak originated from iron species was not found in both samples. This indicates that mesoporous structure of metal-containing carbon nitride compounds did not disrupt the crystal structure of graphitic metal-containing carbon nitride compounds. Thus, it could be inferred that the iron species in $\mathrm{m}-\mathrm{Fe}-\mathrm{C}_{3} \mathrm{~N}_{4}$ was chemically coordinated to the g- $\mathrm{C}_{3} \mathrm{~N}_{4}$ host [12].

To get insight into the surface functionalities created by mesoporous structure, XPS measurements were performed. XPS survey scan spectra show C1s and N1s peaks at $288.1 \mathrm{eV}$ and $398.7 \mathrm{eV}$ in both the $\mathrm{g}-\mathrm{Fe}-\mathrm{C}_{3} \mathrm{~N}_{4}$ and $\mathrm{m}-\mathrm{Fe}-\mathrm{C}_{3} \mathrm{~N}_{4}$ samples (data not shown). The $\mathrm{Cls}$ binding energy shows mainly one carbon species, corresponding to a $\mathrm{C}-\mathrm{N}-\mathrm{C}$ coordination. In the N1s spectrum the main signal shows the existence of C$\mathrm{N}-\mathrm{C}$ groups [18]. The assignment of peaks in the C1s and N1s spectra of two samples was in good agreement with the literature report [12]. It could be seen that $\mathrm{C}-\mathrm{N}$ bonds were 


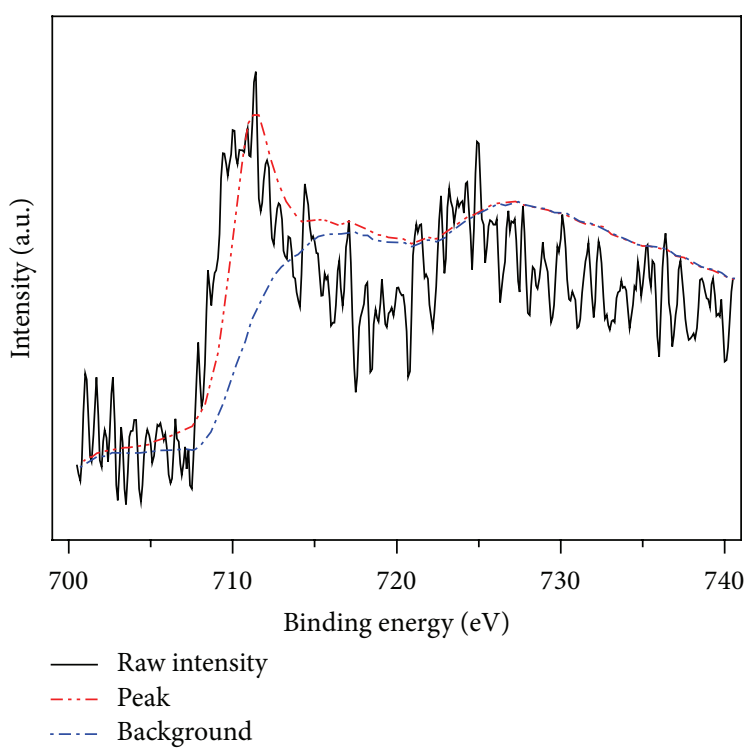

(a)

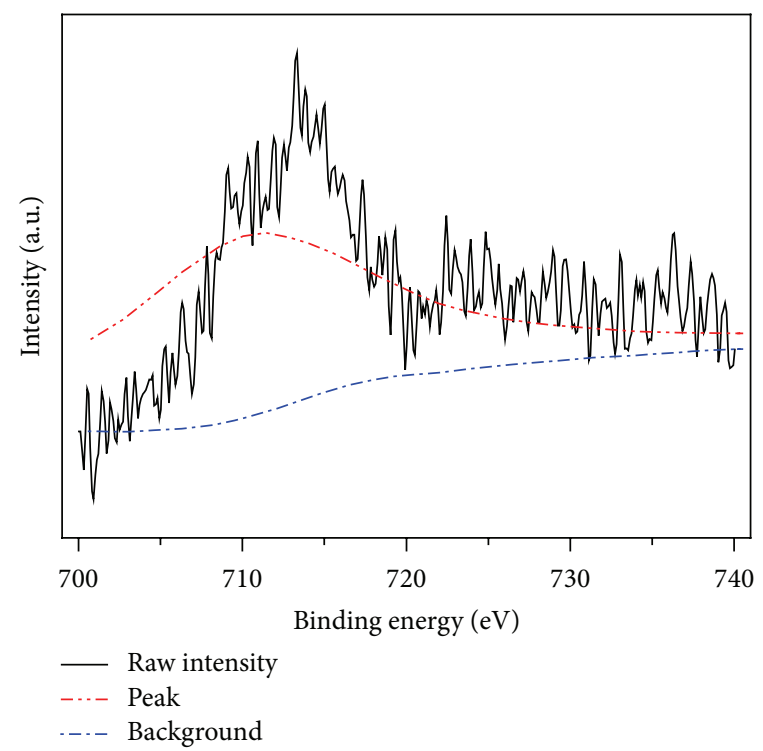

(b)

FIgure 2: XPS spectra of Fe2p for g-Fe- $\mathrm{C}_{3} \mathrm{~N}_{4}$ (a) and $\mathrm{m}-\mathrm{Fe}-\mathrm{C}_{3} \mathrm{~N}_{4}$ (b).

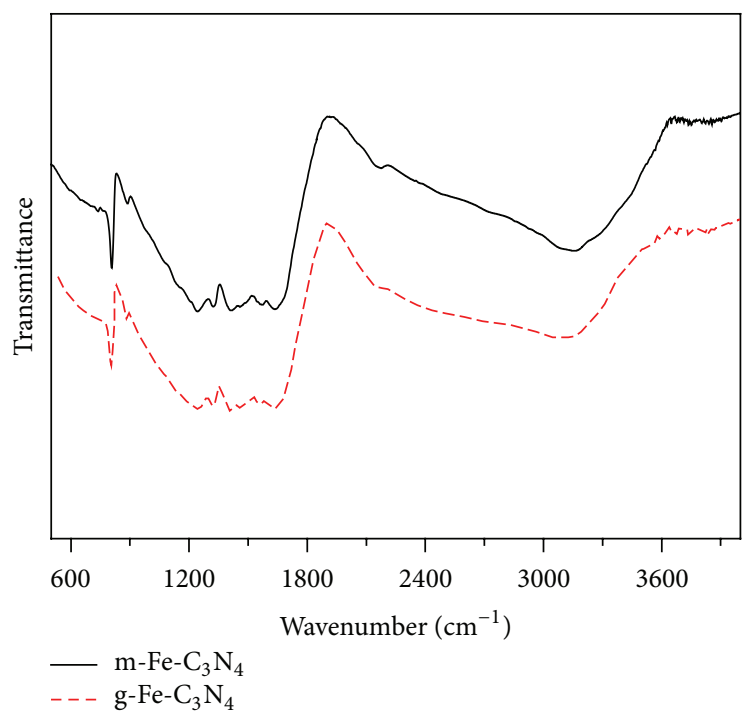

FIgURE 3: FTIR spectra of the g- $\mathrm{Fe}-\mathrm{C}_{3} \mathrm{~N}_{4}$ and $\mathrm{m}-\mathrm{Fe}-\mathrm{C}_{3} \mathrm{~N}_{4}$ samples.

not broken by doping Fe and the formation of mesoporous structure, while the mesoporous structure strengthened C1s and N1s peaks. The high resolution Fe2p XPS spectra shown in Figure 2 are characterized by a broad peak in the range of $700-740 \mathrm{eV}$. The typical XPS spectrum of $\mathrm{m}-\mathrm{Fe}-\mathrm{C}_{3} \mathrm{~N}_{4}$ revealed a Fe2p binding energy peak at $710.1 \mathrm{eV}$, which was lower than the value of $711.2 \mathrm{eV}$ measured for $\mathrm{g}-\mathrm{Fe}-\mathrm{C}_{3} \mathrm{~N}_{4}$ They all fell within the range of binding energy of $\mathrm{Fe}$ (III) state, and only a small amount of $\mathrm{Cl}$ could be detected. This result implies that $\mathrm{Fe}(\mathrm{III})$ is connected to $\mathrm{C}_{3} \mathrm{~N}_{4}$ framework mainly through $\mathrm{Fe}-\mathrm{N}$ bonds, while little was used for charge balance by $\mathrm{Cl}^{-}$ions. Thus, $\mathrm{Fe}$ (III) in $\mathrm{m}-\mathrm{Fe}-\mathrm{C}_{3} \mathrm{~N}_{4}$ might also be stabilized in the electron-rich $\mathrm{C}_{3} \mathrm{~N}_{4}$ structure like g-Fe- $\mathrm{C}_{3} \mathrm{~N}_{4}$.
Figure 3 shows the FTIR spectra of the $\mathrm{g}-\mathrm{Fe}-\mathrm{C}_{3} \mathrm{~N}_{4}$ and $\mathrm{m}$ $\mathrm{Fe}-\mathrm{C}_{3} \mathrm{~N}_{4}$ samples. They exhibit a peak at $808 \mathrm{~cm}^{-1}$ and several other major bands from 1200 to $1700 \mathrm{~cm}^{-1}$. The two samples show stretching modes in the $1200-1700 \mathrm{~cm}^{-1}$ region, which were typical stretching modes of $\mathrm{CN}$ heterocycles originating from the extended $\mathrm{C}_{3} \mathrm{~N}_{4}$ network [19], whereas the sharp band at about $808 \mathrm{~cm}^{-1}$ should be attributed to ring-sextant bending vibration characteristic of triazine or heptazine ring systems $[20,21]$. The results indicate that both the samples were chemically coordinated to the $\mathrm{C}_{3} \mathrm{~N}_{4}$ host and formed no metal nitrides or metal carbides.

Figure 4 shows TEM images of the g-Fe- $\mathrm{C}_{3} \mathrm{~N}_{4}$ and $\mathrm{m}$ $\mathrm{Fe}-\mathrm{C}_{3} \mathrm{~N}_{4}$ samples. These results indicate that the pore size 


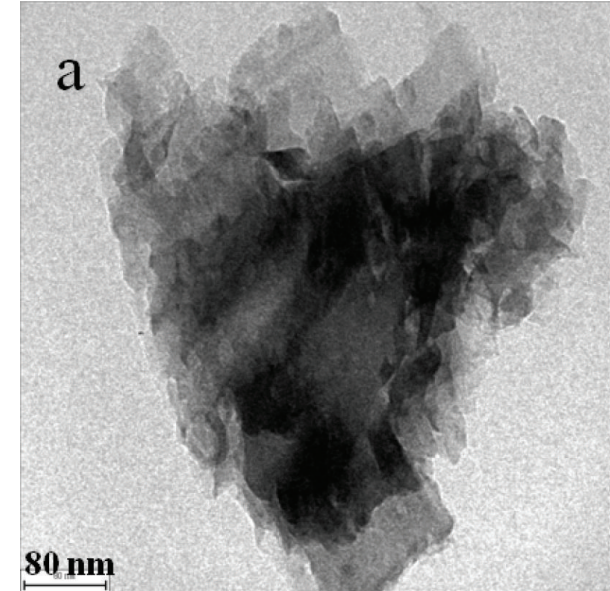

(a)

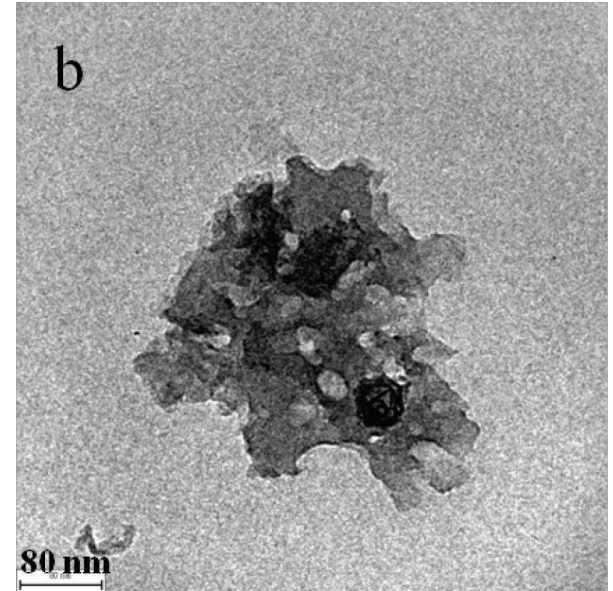

(b)

Figure 4: TEM images of the g-Fe- $\mathrm{C}_{3} \mathrm{~N}_{4}$ and $\mathrm{m}-\mathrm{Fe}-\mathrm{C}_{3} \mathrm{~N}_{4}$ samples.

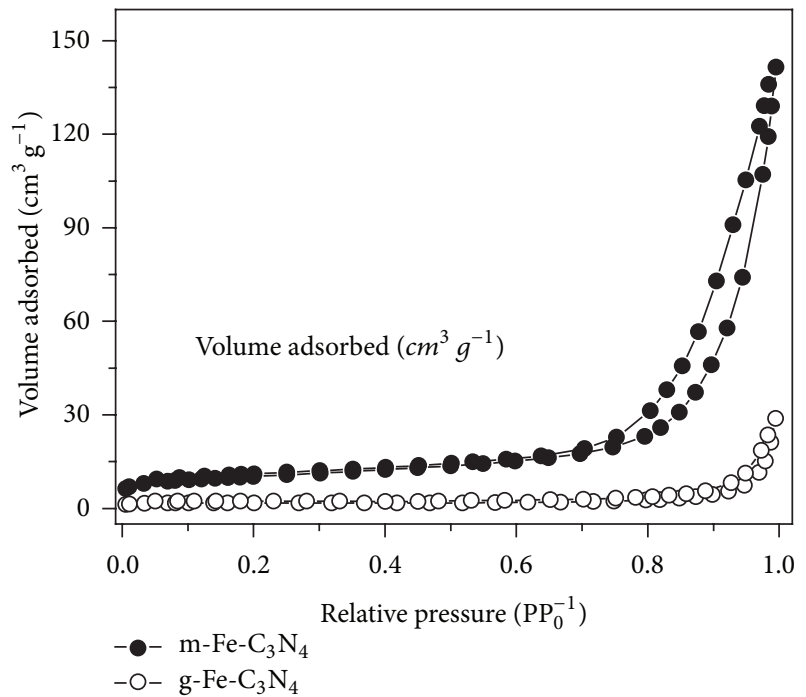

(a)

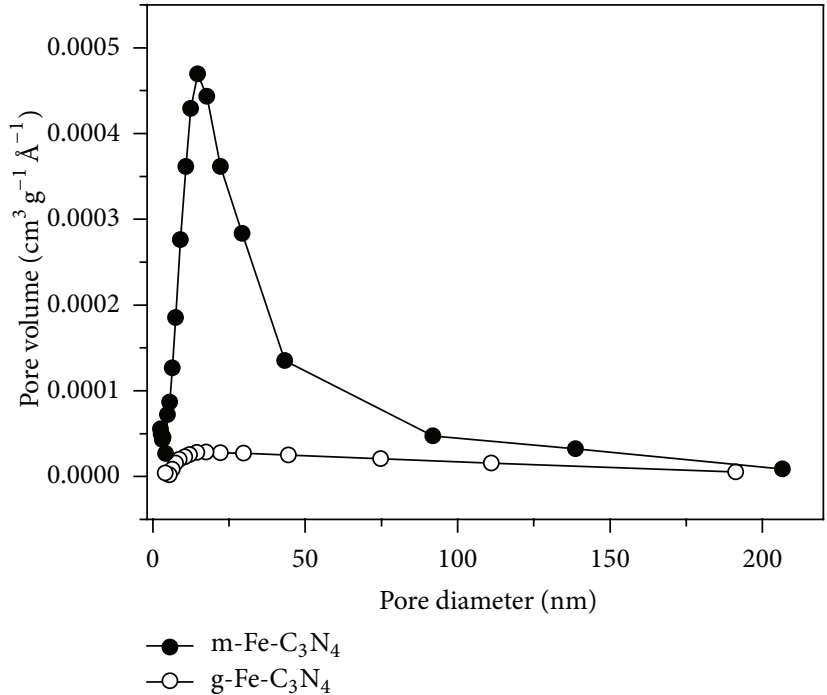

(b)

FiguRE 5: $\mathrm{N}_{2}$ adsorption-desorption isotherms (a) and Barret-Joyner-Halenda (BJH) pore size distribution plots (b) of g-Fe- $\mathrm{C}_{3} \mathrm{~N}_{4}$ and $\mathrm{m}$-Fe$\mathrm{C}_{3} \mathrm{~N}_{4}$ samples.

and connectivity of those powders exactly reflect the geometric properties of the original template [2]. The g-Fe- $\mathrm{C}_{3} \mathrm{~N}_{4}$ shows a graphitic-like and two-dimensional layer structure (Figure 4(a)), which is similar to that of pure $\mathrm{g}-\mathrm{C}_{3} \mathrm{~N}_{4}$. The TEM image of $\mathrm{m}-\mathrm{Fe}-\mathrm{C}_{3} \mathrm{~N}_{4}$ in Figure 4(b) shows disordered pore system of spherical pores with diameter of $15-20 \mathrm{~nm}$, which is consistent with the size of $\mathrm{SiO}_{2}$ template. Compared to $\mathrm{g}-\mathrm{Fe}-\mathrm{C}_{3} \mathrm{~N}_{4}, \mathrm{~m}-\mathrm{Fe}-\mathrm{C}_{3} \mathrm{~N}_{4}$ exhibited a slightly less dense structure and a higher surface area.

Figure 5 shows nitrogen adsorption/desorption isotherms of the $\mathrm{g}-\mathrm{Fe}-\mathrm{C}_{3} \mathrm{~N}_{4}$ and $\mathrm{m}-\mathrm{Fe}-\mathrm{C}_{3} \mathrm{~N}_{4}$ samples. The isotherms of both samples exhibit type III behavior according to the IUPAC classification, indicating the existence of porous structures in the samples [22]. The BET surface area of the $\mathrm{m}-\mathrm{Fe}-\mathrm{C}_{3} \mathrm{~N}_{4}$ sample $\left(35.9 \mathrm{~m}^{2} \mathrm{~g}^{-1}\right)$ was much higher than that of $\mathrm{m}-\mathrm{Fe}-\mathrm{C}_{3} \mathrm{~N}_{4}$ sample $\left(5.7 \mathrm{~m}^{2} \mathrm{~g}^{-1}\right)$. The larger pore volume of $\mathrm{m}-\mathrm{Fe}-\mathrm{C}_{3} \mathrm{~N}_{4}$ sample $\left(0.17 \mathrm{~cm}^{3} \mathrm{~g}^{-1}\right)$ suggested that it was more porous compared with that of $\mathrm{g}-\mathrm{Fe}-\mathrm{C}_{3} \mathrm{~N}_{4}$ sample $\left(0.02 \mathrm{~cm}^{3} \mathrm{~g}^{-1}\right)$. An average pore diameter of $18.4 \mathrm{~nm}$ for $\mathrm{m}$ Fe- $\mathrm{C}_{3} \mathrm{~N}_{4}$ can be estimated from the $\mathrm{BJH}$ pore size distribution (Figure 5(b)). The pore size distribution of the two samples obtained from its absorption isotherm is consistent with the observed pore sizes from the TEM image. These results illustrate that $\mathrm{m}-\mathrm{Fe}-\mathrm{C}_{3} \mathrm{~N}_{4}$ sample has been introduced with porous structure, which results in an increased surface area, enlarged pore volume, and narrow pore size distribution.

Figure 6 shows the optical absorbance spectra of the g$\mathrm{Fe}-\mathrm{C}_{3} \mathrm{~N}_{4}$ and $\mathrm{m}-\mathrm{Fe}-\mathrm{C}_{3} \mathrm{~N}_{4}$ samples. The absorption edge was at about $480 \mathrm{~nm}$ for g-Fe- $\mathrm{C}_{3} \mathrm{~N}_{4}$ and $460 \mathrm{~nm}$ for $\mathrm{m}-\mathrm{Fe}-\mathrm{C}_{3} \mathrm{~N}_{4}$, corresponding to the calculated band gap of ca. 2.58 and 


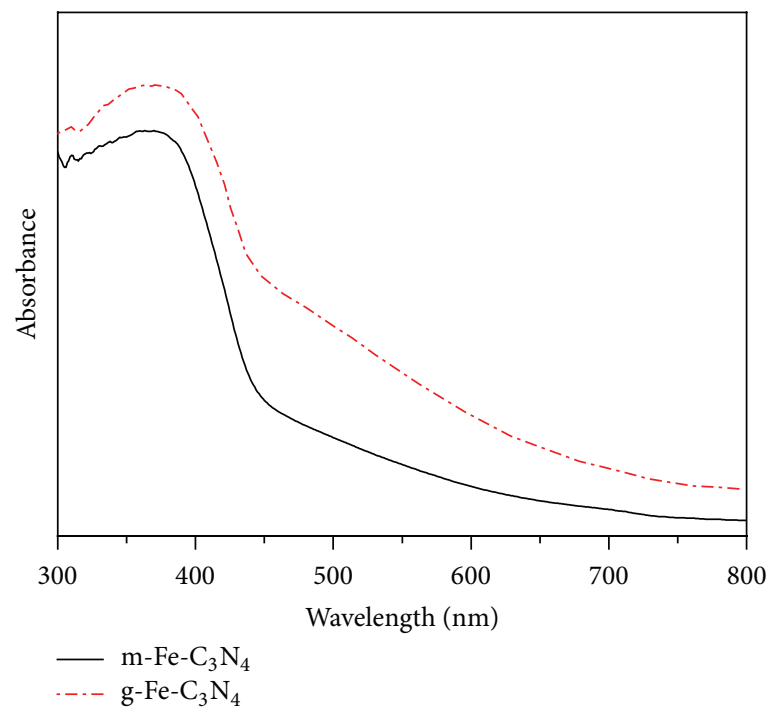

FIgURE 6: UV-vis absorption spectra of the g-Fe- $\mathrm{C}_{3} \mathrm{~N}_{4}$ and $\mathrm{m}-\mathrm{Fe}-\mathrm{C}_{3} \mathrm{~N}_{4}$ samples.

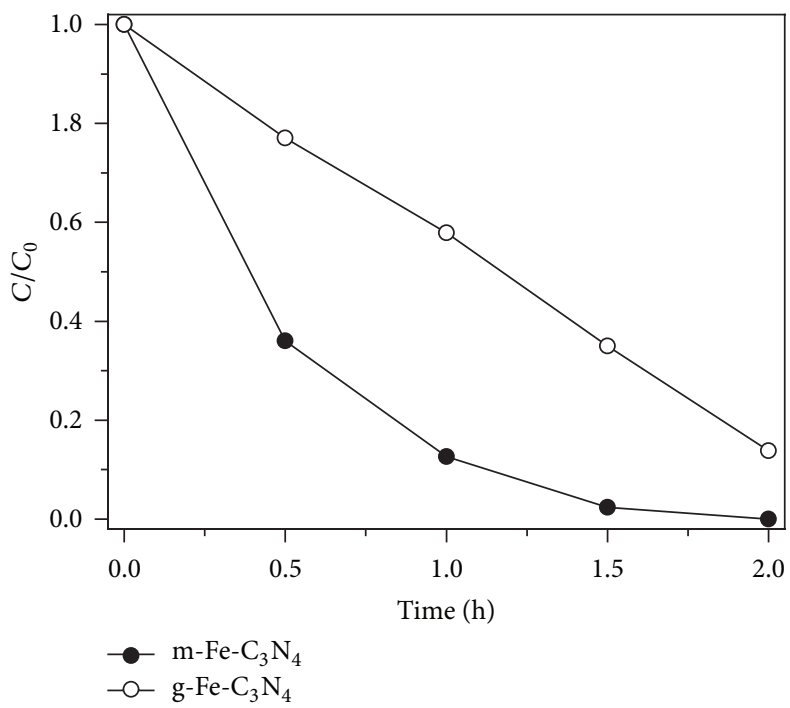

Figure 7: Comparison of the activities of $\mathrm{g}-\mathrm{Fe}-\mathrm{C}_{3} \mathrm{~N}_{4}$ and $\mathrm{m}-\mathrm{Fe}-\mathrm{C}_{3} \mathrm{~N}_{4}$ samples for $\mathrm{RhB}$ photocatalytic degradation.

$2.70 \mathrm{eV}$, respectively. The comparison on the spectra of g-Fe$\mathrm{C}_{3} \mathrm{~N}_{4}$ and $\mathrm{m}-\mathrm{Fe}-\mathrm{C}_{3} \mathrm{~N}_{4}$ samples indicates that the mesoporous structure of metal-containing carbon nitride compounds altered the electronic structure, and meantime the band gap was increased. Such structural change would lower the visible light response, though it might enhance the transport efficiencies of electrons and holes.

The photocatalytic performance of the resultant samples for $\mathrm{RhB}$ degradation under irradiation is shown in Figure 7. The results indicate that the mesoporous structure greatly influences the photocatalytic performance of g-Fe- $\mathrm{C}_{3} \mathrm{~N}_{4}$ materials. The g- $\mathrm{Fe}-\mathrm{C}_{3} \mathrm{~N}_{4}$ showed a moderate photoreactivity toward organics degradation, which is consistent with the literature report [11]. Only $\sim 42 \%$ of $\mathrm{RhB}$ was degraded in $60 \mathrm{~min}$ by $\mathrm{g}-\mathrm{Fe}-\mathrm{C}_{3} \mathrm{~N}_{4}$ under irradiation, which is much lower than that of mesoporous samples. The $\mathrm{m}-\mathrm{Fe}-\mathrm{C}_{3} \mathrm{~N}_{4}$ sample exhibits a higher photocatalytic activity, with nearly $88 \%$ and $98 \%$ of $\mathrm{RhB}$ degraded after 60 and 90 min irradiation, respectively. The $\mathrm{m}-\mathrm{Fe}-\mathrm{C}_{3} \mathrm{~N}_{4}$ sample showed much higher efficiency in $\mathrm{RhB}$ degradation than $\mathrm{g}-\mathrm{Fe}-\mathrm{C}_{3} \mathrm{~N}_{4}$ under irradiation. It is known that the photooxidation reactions of organic molecules can directly utilize the generated valence band holes or the main generated active species, ${ }^{\circ} \mathrm{OH}$ radicals, from the reaction of holes with surface adsorbed water or hydroxyl groups [10]. The mesoporous structure is beneficial for promoting the mass transfer of reactants and products, enhancing the photocatalytic activity by facilitating access to the reactive sites on the surface photocatalyst. Generally, a larger surface area of photocatalysts is favorable for photocatalytic reaction by providing more possible reaction sites [23]. In addition, the unique electronic structure of $\mathrm{m}$ $\mathrm{Fe}-\mathrm{C}_{3} \mathrm{~N}_{4}$ may also contribute considerably to the excellent photooxidation reactivity. 


\section{Conclusions}

In summary, in situ Fe-doped mesoporous $\mathrm{g}-\mathrm{C}_{3} \mathrm{~N}_{4}$ was synthesized from a single precursor, dicyandiamide, by using $\mathrm{SiO}_{2}$ nanoparticles as the template. The XRD results indicate that $\mathrm{Fe}$ is strongly coordinated with the g- $\mathrm{C}_{3} \mathrm{~N}_{4}$ matrix and that the doping and mesoporous structure partly deteriorates its crystalline structure. The XPS analysis confirmed that Fe species was coordinated with the $\mathrm{g}-\mathrm{Fe}-\mathrm{C}_{3} \mathrm{~N}_{4}$ and $\mathrm{m}$ $\mathrm{Fe}-\mathrm{C}_{3} \mathrm{~N}_{4}$ framework through $\mathrm{Fe}-\mathrm{N}$ bonds. The UV-visible absorption spectra reveal that the absorption edge of g-Fe$\mathrm{C}_{3} \mathrm{~N}_{4}$ was redshifted from $460 \mathrm{~nm}$ of the $\mathrm{m}-\mathrm{Fe}-\mathrm{C}_{3} \mathrm{~N}_{4}$ sample to $480 \mathrm{~nm}$ together with a stronger light absorbance, implying that the formation of mesoporous structure changes the electronic properties of $\mathrm{g}-\mathrm{Fe}-\mathrm{C}_{3} \mathrm{~N}_{4}$. The obtained Fe-doped mesoporous $\mathrm{g}-\mathrm{C}_{3} \mathrm{~N}_{4}$ shows much higher activity than the g-Fe- $\mathrm{C}_{3} \mathrm{~N}_{4}$ for $\mathrm{RhB}$ degradation. This activity enhancement could be attributed to the increased surface area and unique mesoporous structure.

\section{References}

[1] Y. Wang, X. Wang, and M. Antonietti, "Polymeric graphitic carbon nitride as a heterogeneous organocatalyst: from photochemistry to multipurpose catalysis to sustainable chemistry," Angewandte Chemie-International Edition, vol. 51, no. 1, pp. 68-89, 2012.

[2] F. Goettmann, A. Fischer, M. Antonietti, and A. Thomas, "Chemical synthesis of mesoporous carbon nitrides using hard templates and their use as a metal-free catalyst for FriedelCrafts reaction of benzene," Angewandte Chemie-International Edition, vol. 45, no. 27, pp. 4467-4471, 2006.

[3] X. Wang, K. Maeda, A. Thomas et al., "A metal-free polymeric photocatalyst for hydrogen production from water under visible light," Nature Materials, vol. 8, no. 1, pp. 76-80, 2009.

[4] P. Niu, G. Liu, and H. M. Cheng, "Nitrogen vacancy-promoted photocatalytic activity of graphitic carbon nitride," The Journal of Physical Chemistry C, vol. 116, no. 20, pp. 11013-11018, 2012.

[5] S. C. Yan, Z. S. Li, and Z. G. Zou, "Photodegradation performance of $\mathrm{g}^{-} \mathrm{C}_{3} \mathrm{~N}_{4}$ fabricated by directly heating melamine," Langmuir, vol. 25, no. 17, pp. 10397-10401, 2009.

[6] M. Groenewolt and M. Antonietti, "Synthesis of g- $\mathrm{C}_{3} \mathrm{~N}_{4}$ nanoparticles in mesoporous silica host matrices," Advanced Materials, vol. 17, no. 14, pp. 1789-1792, 2005.

[7] Y. Wang, H. Li, J. Yao, X. Wang, and M. Antonietti, "Synthesis of boron doped polymeric carbon nitride solids and their use as metal-free catalysts for aliphatic C-H bond oxidation," Chemical Science, vol. 2, no. 3, pp. 446-450, 2011.

[8] X. Wang, K. Maeda, X. Chen et al., "Polymer semiconductors for artificial photosynthesis: hydrogen evolution by mesoporous graphitic carbon nitride with visible light," Journal of the American Chemical Society, vol. 131, no. 5, pp. 1680-1681, 2009.

[9] Y. Wang, Y. Di, M. Antonietti, H. Li, X. Chen, and X. Wang, "Excellent visible-light photocatalysis of fluorinated polymeric carbon nitride solids," Chemistry of Materials, vol. 22, no. 18, pp. 5119-5121, 2010.

[10] G. Liu, P. Niu, C. Sun et al., "Unique electronic structure induced high photoreactivity of sulfur-doped graphitic $\mathrm{C}_{3} \mathrm{~N}_{4}$," Journal of the American Chemical Society, vol. 132, no. 33, pp. 1164211648, 2010.
[11] X. Wang, X. Chen, A. Thomas, X. Fu, and M. Antonietti, "Metal-containing carbon nitride compounds: a new functional organic-metal hybrid material," Advanced Materials, vol. 21, no. 16, pp. 1609-1612, 2009.

[12] Z. Ding, X. Chen, M. Antonietti, and X. Wang, "Synthesis of transition metal-modified carbon nitride polymers for selective hydrocarbon oxidation," ChemSusChem, vol. 4, no. 2, pp. 274281, 2011.

[13] B. Yue, Q. Li, H. Iwai, T. Kako, and J. Ye, "Hydrogen production using zinc-doped carbon nitride catalyst irradiated with visible light," Science and Technology of Advanced Materials, vol. 12, no. 3, Article ID 034401, 7 pages, 2011.

[14] X. Chen, J. Zhang, X. Fu, M. Antonietti, and X. Wang, "Fe-g$\mathrm{C}_{3} \mathrm{~N}_{4}$-catalyzed oxidation of benzene to phenol using hydrogen peroxide and visible light," Journal of the American Chemical Society, vol. 131, no. 33, pp. 11658-11659, 2009.

[15] G. J. D. A. A. Soler-Illia, C. Sanchez, B. Lebeau, and J. Patarin, "Chemical strategies to design textured materials: from microporous and mesoporous oxides to nanonetworks and hierarchical structures," Chemical Reviews, vol. 102, no. 11, pp. 4093-4138, 2002.

[16] Y. Zhang, J. Liu, G. Wu, and W. Chen, "Porous graphitic carbon nitride synthesized via direct polymerization of urea for efficient sunlight-driven photocatalytic hydrogen production," Nanoscale, vol. 4, no. 17, pp. 5300-5303, 2012.

[17] F. Dong, L. Wu, Y. Sun, M. Fu, Z. Wu, and S. C. Lee, "Efficient synthesis of polymeric g- $\mathrm{C}_{3} \mathrm{~N}_{4}$ layered materials as novel efficient visible light driven photocatalysts," Journal of Materials Chemistry, vol. 21, no. 39, pp. 15171-15174, 2011.

[18] A. Thomas, A. Fischer, F. Goettmann et al., "Graphitic carbon nitride materials: variation of structure and morphology and their use as metal-free catalysts," Journal of Materials Chemistry, vol. 18, no. 41, pp. 4893-4908, 2008.

[19] J. D. Hong, X. Y. Xia, Y. S. Wang, and R. Xu, "Mesoporous carbon nitride with in situ sulfur doping for enhanced photocatalytic hydrogen evolution from water under visible light," Journal of Materials Chemistry, vol. 22, pp. 15006-15012, 2012.

[20] B. V. Lotsch, M. Döblinger, J. Sehnert et al., "Unmasking melon by a complementary approach employing electron diffraction, solid-state NMR spectroscopy, and theoretical calculationsstructural characterization of a carbon nitride polymer," Chemistry-A European Journal, vol. 13, no. 17, pp. 4969-4980, 2007.

[21] B. V. Lotsch and W. Schnick, "From triazines to heptazines: novel nonmetal tricyanomelaminates as precursors for graphitic carbon nitride materials," Chemistry of Materials, vol. 18, no. 7, pp. 1891-1900, 2006.

[22] G. Dong and L. Zhang, "Porous structure dependent photoreactivity of graphitic carbon nitride under visible light," Journal of Materials Chemistry, vol. 22, no. 3, pp. 1160-1166, 2012.

[23] E. Martínez-Ferrero, Y. Sakatani, C. Boissière et al., "Nanostructured titanium oxynitride porous thin films as efficient visibleactive photocatalysts," Advanced Functional Materials, vol. 17, no. 16, pp. 3348-3354, 2007. 

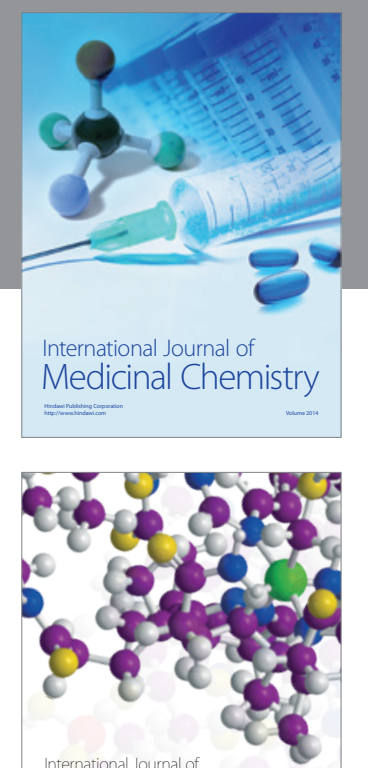

\section{Carbohydrate} Chemistry

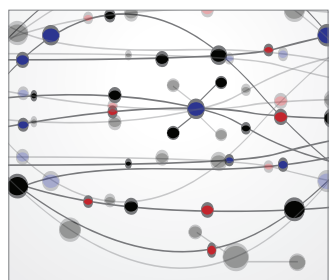

The Scientific World Journal
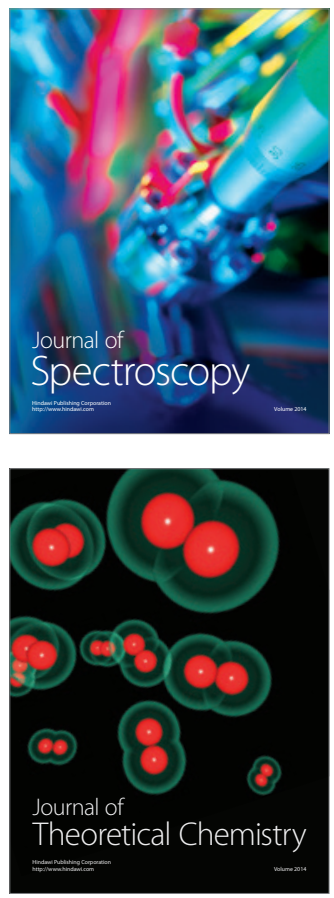
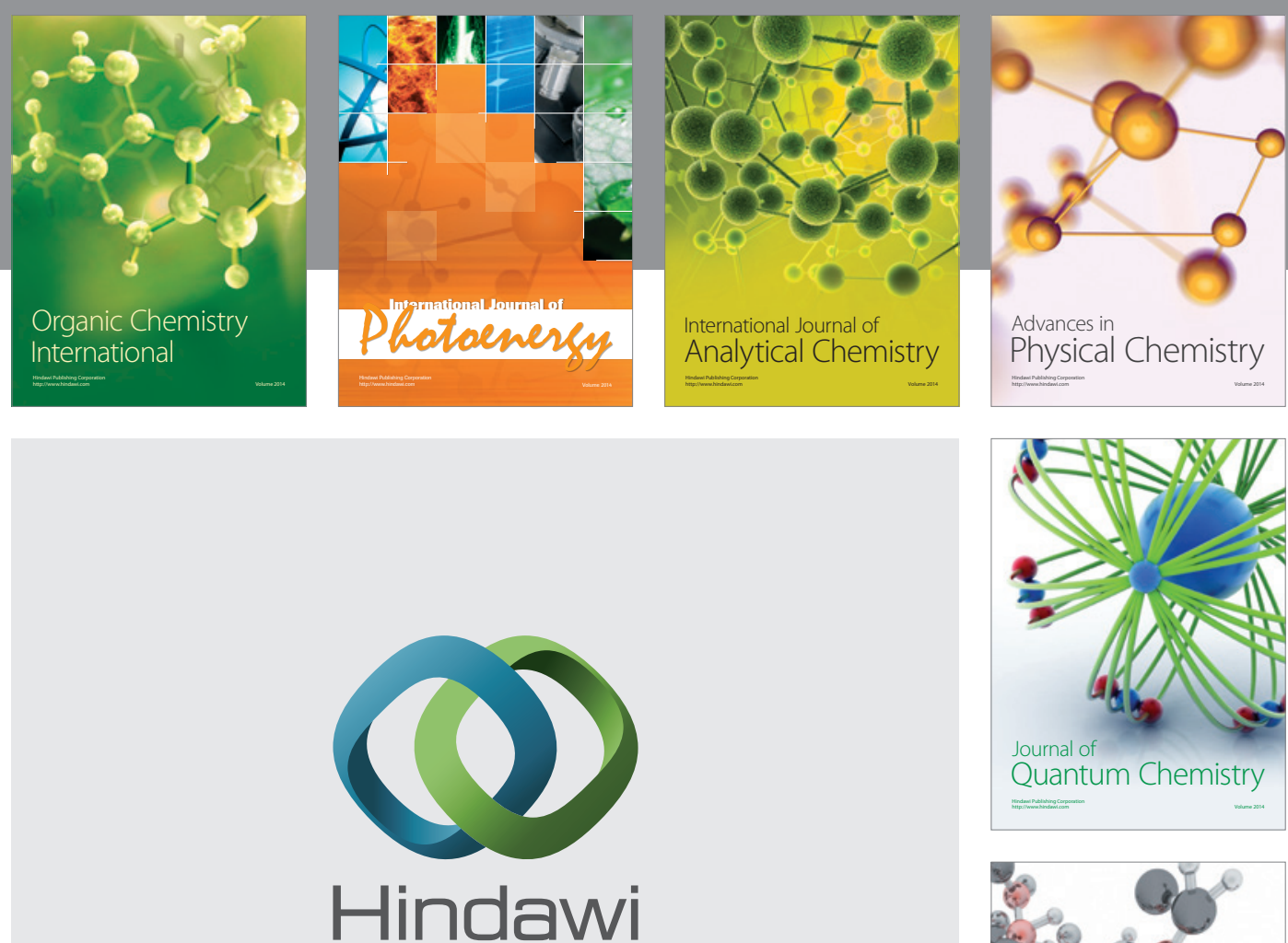

Submit your manuscripts at

http://www.hindawi.com

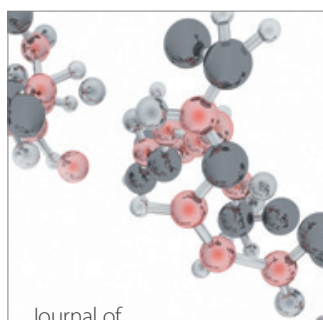

Analytical Methods

in Chemistry

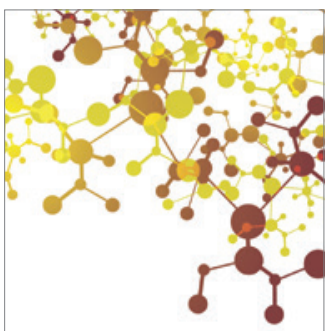

Journal of

Applied Chemistry

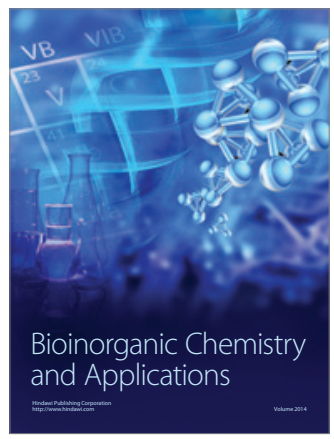

Inorganic Chemistry
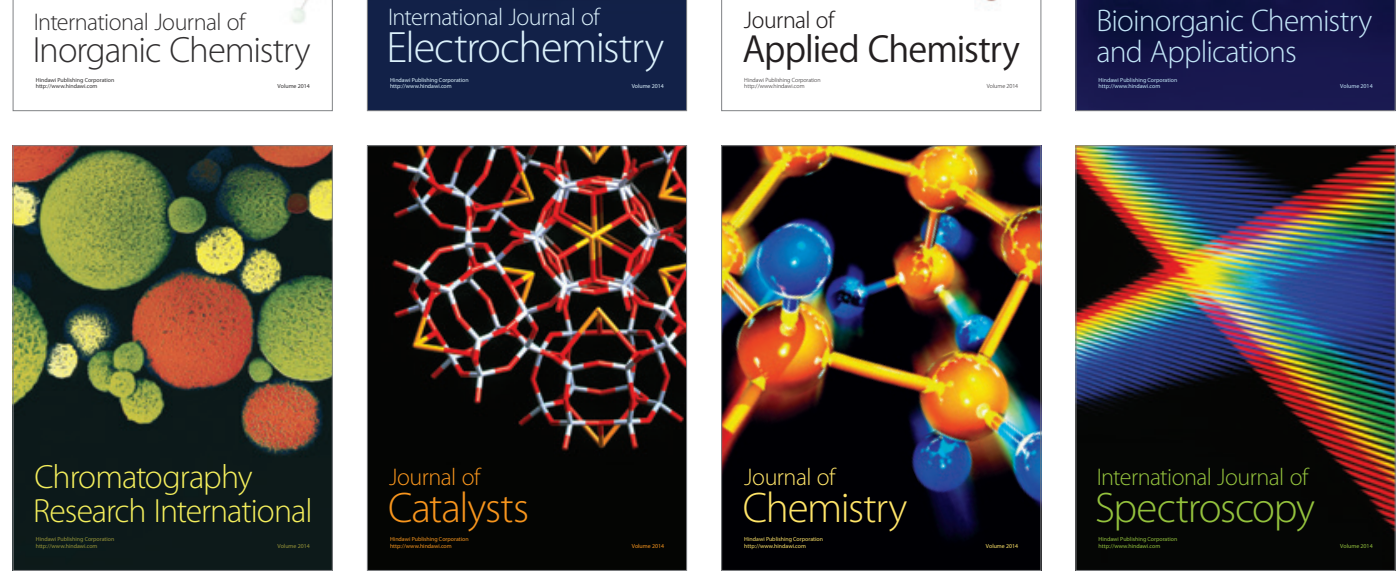